\title{
Modern Trends in Financing Infrastructure Projects in the Framework of Public-Private Partnership
}

\author{
Yuzvovich L.I. ${ }^{*}$ Boytush O.A. Pustovalova L.M. \\ Ural state University of Economics, Russia, 620144, Yekaterinburg, 8 Marta st., 62-557 \\ *Corresponding author.E-mail: yuzvovich@bk.ru
}

\begin{abstract}
The Russian economy is gradually evolving towards the Western model of financing of growth. The availability of sources of financing of investments is currently one of the main problems in investment activity. In many countries of the world, the number of sources of financing exceeds the number of sources of financing in Russia. With the transition of Russia to market relations, there is a heavy deficit of sources of financing. The system of financing of investments consists of an organic unity of sources of financing of investment activity and investment methods. Financing of investment projects can be carried out from either one or several sources. In general, all sources of financing are divided into: centralized (budgetary) and decentralized (extra-budgetary). Centralized sources usually include federal funds, funds from the budgets of the constituent entities of the Russian Federation and local budgets. All the rest are decentralized. Extrabudgetary funds include own funds of enterprises and organizations, borrowed, external funds, funds of extrabudgetary funds, private developers, foreign investments.
\end{abstract}

Keywords: financing, infrastructure projects, public-private partnership

\section{INTRODUCTION}

The relevance of the study is determined by the growing needs for financing of infrastructure projects, in particular the transport network. Thus, the relevance and discussion of the study topic, high practical significance predetermined the purpose and objectives of the study.

In the conditions of a permanent financial crisis, the main source of financing of investment projects, of course, is the federal budget. The recipients of state investments can be state-owned enterprises, as well as legal entities, involved in the implementation of state programs. The financing of state investment is carried out in accordance with the level of decision-making.

At the federal level, federal programs and federal-owned objects are financed, at the regional level - regional programs and objects, owned by certain specific territories. Financing of facilities, constructed for state needs, can be repayable and irreparable. Irreparable financing is carried out to develop fundamentally new areas of production activity. In addition, federal funds are allocated on an irreparable basis for the implementation of conversion, defense, environmental and other similar facilities, that are not designed for commercial impact or its quick receipt.

The rationale for the financing strategy of an investment project involves the selection of financing methods, determination of the sources of financing of investments and their structure.

The method of financing of an investment project acts as a way to raise investment sources in order to ensure financial implementability of the project [2]. The following methods were chosen as methods of financing of state investment projects:

\section{Budget financing;}

- $\quad$ appropriations from the federal budget and budgets of constituent entities of the Russian Federation;

- federal target programs;

- $\quad$ subfederal bonds.

2. Foreign investments;

- borrowed sources of financing

- bank crediting;

3. Public-private partnership

- budget co-financing;

- concessionaire agreements;

- infrastructure (concessionaire) bonds;

- deferred tax payments mechanism;

- project financing. 
The scientific article considers different methods and ways of financing of infrastructure facilities with distinguishing their advantages and disadvantages.

\section{ANALYSIS OF RECENT ACHIEVEMENTS AND PUBLICATIONS, IN WHICH THE SOLUTION TO THIS PROBLEM WAS STARTED, THE DISTINGUISHING OF PREVIOUSLY UNSOLVED PARTS OF THE GENERAL PROBLEM, TO WHICH THIS ARTICLE IS DEDICATED}

The theoretical and methodological basis of the study combines the provisions of economic and financial science in the classical and modern understanding of the conceptual positions of the theory of financing of investment projects, including with the participation of the state in the framework of concessions and public-private partnerships, monographic scientific publications, that reveal the patterns of financing of real investments; program and methodological developments of real investment market participants, on the basis of which a theoretical base of the studied issues is developed.

The empirical basis of the research in its theoretical part is the works of Russian and foreign scientists, as well as specialists in the field of system of financing of infrastructure projects, in particular Alpatov A.A., Varnavsky V.G., Shevelkina K.L., Plaksin V.K., David Gonzalez-Ruiz, Juan; Pena, Alejandro; Alexander Duque, Eduardo, Lu, Zheng; Pena-Mora, Feniosky; Wang, S. Q., Rarasati, Ayomi Dita; Trigunarsyah, Bambang; Lamari, Fiona, Mohan, Giles; Tan-Mullins, Veebel, Villar; Marcus, Raul; Bad, Illimar and others.

The practical part of the study information base consisted of federal laws and regulatory acts of the Russian Federation on the financing of infrastructure projects of the transport network, analytical materials of scientific and practical conferences; expert information of periodicals; reference materials and electronic information systems. The information base is quite representative, in connection with this there is a reliable basis for creating an complex approach to develop a concept of financing of infrastructure projects using concession mechanisms in the framework of public-private partnership.

The degree of scientific development of the topic. The discussion of the problems of financing infrastructure facilities in the urban transport network in the context of modernization of the Russian logistics market should be adequately reflected in scientific and applied studies, revealing the theoretical and methodological aspects of the activities of participants in infrastructure projects in terms of financing them.

\section{FORMULATION OF PURPOSE AND STATEMENT OF STUDY OBJECTIVES}

The purpose of the study is to develop a comprehensive concept of financing of infrastructure facilities of the transport network of a municipal unit, based on publicprivate partnership instruments.

The objective, stated in a scientific article, required the solution of specific theoretical and practical study problems:

- $\quad$ study existing models of financing of infrastructure projects;

- consider modern ways of financing of infrastructure facilities;

- analyze and choose the best financing methods, under the conditions of existing restrictions.

The subject of the study is economic relations, arising in the process of financing of infrastructure projects of the transport network.

\section{PRESENTATION OF THE MAIN STUDY MATERIAL WITH FULL SUBSTANTIATION OF THE OBTAINED SCIENTIFIC RESULTS, FORMULATION OF RECOMMENDATIONS}

In general, the development of economic infrastructure systems requires a behavioral comprehensive analysis of various financial variables or rates to establish their longterm success in relation to the expected internal rate of return of stock capital (EIRR). For this reason, some financial institutions developed economic scenarios, supported by computational methods and models to identify the evolution of these financial rates. However, these models and methods showed a number of limitations regarding the financial management process and its influence on EIRR over time. For a complex solution to these problems, researchers developed various approaches and methodologies, focused on the development of financial models, using stochastic modeling methods and computational intelligence methods [13].

Currently, in the world, updating and the need to study the issues of financing of infrastructure projects is being considered and modeled in various sectors of the economy, taking into account strategic directions of development $[14,15,16,17,18]$

As for the Russian economy, appropriations from the federal budget and the budgets of the constituent entities of the Russian Federation are allocated for financing of priority production facilities of national economic importance in accordance with the approved federal target programs. Budget financing has a number of principles [1]:

- obtaining the maximum economic and social effect with minimum costs; 
- $\quad$ target nature of the use of budget resources;

- the provision of budgetary funds to construction sites and contracting organizations to the extent of plan performance and taking into account the use of previously allocated appropriations.

Federal targeted programs. In Russia, financing of investment projects as part of targeted programs is related to the implementation of federal investment programs (Federal targeted investment program, federal targeted programs), departmental, regional and municipal targeted investment programs.

Federal target programs are an instrument of the programtargeted method of financing of real investments, as well as the implementation of priority objectives in the field of state, economic, and social development of the country. They are funded from the federal budget, the budgets of the constituent entities of the federation, municipal units and extrabudgetary funds. Priority sectors, for which state support in the implementation of investment projects at the expense of the federal budget is required, are determined by the Ministry of economic development and trade and the Ministry of finance of the Russian federation in coordination with other federal government authorities [5]. Facilities, that are mainly of federal importance (constructions and new construction facilities and technical re-equipment for federal state needs), are included in the Federal targeted investment program (FTIP), which determines the volume of state investment by industries and departments. The list of objects, financed by the FTIP, is formed on the basis of the volume of state capital investments, allocated for the implementation of federal targeted programs, as well as for the solution of certain important socio-economic issues, not included in these programs on the basis of proposals, approved by the decisions of the President of the Russian Federation or the Government of the Russian Federation. The formation of this list is carried out by the Ministry of economic development and trade of the Russian Federation taking into account the proposals of state customers on investment projects, the results of contract tenders and concluded state contracts.

As mentioned above, budget financing of real investment projects is carried out, as a rule, through financing under targeted programs and financial support of the Investment fund of the Russian Federation, the latter was abolished in 2017. Nevertheless, to study the experience of creating projects with the participation of the Investment fund of the Russian Federation wouldn't be superfluous in the scope of this work, since in many cases non-trivial financing models and a diverse project membership were used. The Investment fund of the Russian Federation was created to implement investment projects of national importance and carried out on the basis of public-private partnerships. The main directions of state support at the costs of this fund are associated with the modernization of noncommercial infrastructure, fixed assets and technologies, related to the strategic priorities of the state, as well as the creation and development of the Russian innovation system, and the provision for institutional transformations. The procedure of the formation of the Investment fund of the Russian Federation, the forms, mechanisms and conditions for providing state support at the costs of its funds are determined by the Regulation on the Investment fund of the Russian Federation [7.8]. Financial support for projects, that passed competitive selection, involves the use of such forms, as co-financing on a contractual basis of investment project with registration of state property rights, directing funds to the authorized capitals of legal entities, and providing for state guarantees [11].

In the period from 2006 to 2017, major investment projects in Russia were financed from the Investment fund of the Russian Federation It is assumed, that the state will participate in projects worth at least five billion rubles for five years. A private investor will have to invest at least $25 \%$ of the funds. Project profitability should be at least $4 \%$ and not more than $11 \%$. State support from the investment fund was carried out in three formats [4]:

- direct co-financing of projects;

- $\quad$ participation in the share capital of the company;

- $\quad$ system of state guarantees, which differs from the guarantees of the Ministry of finance.

There are two types of criteria, when choosing projects: qualitative and quantitative. Qualitative criteria include, in particular, national priority.

Quantitative criteria:

- general economic efficiency, expressed in the contribution of the project to the increase in regional and gross domestic product;

- budget efficiency (considered as the ratio of discounted tax intakes to the federal budget and (or) savings of federal budget costs due to the implementation of the project to the total amount of the planned budget appropriations of the Fund.);

- financial efficiency (internal rate of return, payback periods, return on investment index, net present value of the project).

- Quantitative criteria are approved by a joint order of the Ministry of economic development and the Ministry of finance.

Such projects were selected:

- $\quad$ construction of the "Western High-Speed Diameter" (WHSD) highway in St. Petersburg with a total length of forty-seven kilometers. The project budget is approximately eighty billion rubles, including 28 billion rubles of budget funds;

- construction of a new exit to the Moscow Ring Road of the federal highway M-1 Moscow- 
Minsk. Its value is estimated at 17.6 billion rubles. (10.01 billion rubles are allocated from the Investment fund) The project was submitted by the Federal Road Agency. An investor will be selected based on the results of the concession tender, after which the share of state participation in the construction of the road can be reduced;

- $\quad$ construction of the Oryol tunnel under the Neva in St. Petersburg. Its value is 26 billion rubles. (from the Investment fund about 8.8 billion rubles.). This project is planned to be implemented as part of the concession.

Consider the financing structure of one of the above projects in more detail:

Western High Speed Diameter (WHSD) is an global investment project, implemented in St. Petersburg. The creation of the WHSD is the world's largest example of public-private partnership in the field of road construction [6]. This is Russia's first paid urban high-speed traffic highway. The project value is estimated at 212.7 billion rubles, of which 108 billion rubles are investor funds, 71.2 billion rubles. - investment fund, 33.5 billion rubles. - city budget funds. On July 24, 2009, the Government of the Russian Federation decided to reduce the amount of funds, allocated from the Investment fund of the Russian Federation, for the construction of WHSD in St. Petersburg by 20.5 billion rubles [12]. The amount of funds for the implementation of the project remained the same - 212.7 billion rubles. At the same time, the amount of the Investment Fund's funds was reduced from 71.2 to 50.7 billion rubles, and the funds, allocated by the regional budget, were increased from 33.6 to 54.1 billion rubles. Financing by the investor increased slightly - by 1 billion rubles. and will amount to 107.863 billion rubles. The date of completion of the construction is postponed from 2013 to 2016.

According to the data, published at the end of 2016, 36 billion rubles from the budget were spent on the construction of the northern section, 47 billion rubles from the budget - for the construction of the southern section, the construction of the central section is estimated at 128 billion rubles: of which 51 billion rubles were allocated from the budget as a grant, LLC "Northern Capital Highway" raised more than 72 billion rubles of its own and credit funds. The structure of financing, raised by $\mathrm{NCH}$, is as follows:

- Vnesheconombank - 25 billion rubles;

- Eurasian Development Bank - 10 billion rubles;

- VTB and Gazprombank - 17 billion rubles;

- $\quad$ European Bank for Reconstruction and Development - 200 million euros;

- The share capital of $\mathrm{NCH}$ is 9 billion rubles.

As we see in the structure of raised financing, a whole pool of large investors is involved. It is planned, that until 2042, the "NCH" company will be engaged in the operation of the highway and the collection of payments. If at the end of the year the operating earnings are less than 9.6 billion rubles, a subsidy will be allocated from the budget of St. Petersburg to investor for the missing amount under the "maximally compensated costs" mechanism (maintenance costs and repayment of the loan financing and road operation, raised into the project). If the total income is more than 9.6 billion rubles, then $90 \%$ of the excess amount will be allocated in the budget, and $10 \%$ remains as investor income. It was predicted, that in 2016, $\mathrm{NCH}$ could receive 4.1 billion rubles from the budget, and in 2017 - 4.6 billion rubles. In fact, in 2016, a subsidy of 4.6 billion rubles was paid, for 2017 - in the amount of 5.2 billion rubles.

It is planned, that until 2019, subsidies of 17 billion rubles will be allocated from the budget.

The level of subsidies for the most compensated costs was one of the main criteria for an open tender for the selection of a partner of St. Petersburg under the PPP Agreement, which took place nine years ago. Another proposal of BKK "Magistral" (was formed by Sberbank, VINCI, Terra Nova, etc.) amounted to 16.15 billion rubles. subsidies per year [7]. The exact figures and economics of the project are not disclosed, as this agreement is confidential.

Subfederal bonds. With limited and / or insufficient own funds to finance investment goals, and this happens quite often, an entity or state has the possibility to resort to additional financial resources - issues of the Central Bank bonds, shares bills, and other - their circularization in the financial markets significantly increase the possibilities to raise free funds of citizens, corporations and companies for investment, contributing to the mobilization of temporarily free funds of Central Bank market participants for large investments.

One of the sources of raising investments was the issue of government bonds. Adoption of state. bonds can help the real sector of the national economy. The issue of bonds opens a direct source for raising investments for the constituent entities of the Russian Federation and the state. Bonds, issued by a constituent entity of the Russian Federation, are usually called sub-federal.

Subfederal are bonds, issued on behalf of the constituent entities of the Russian Federation.

The issue of subfederal securities is aimed at achieving the following goals:

- financing of the budget deficit of a constituent entities of the Russian Federation;

- $\quad$ financing of targeted programs or specific projects (including repayments from cash proceeds from the project).

- Restrictions on the issue of bonds by a constituent entity of the Russian Federation will be considered in the next chapter.

Benefits of issuing bonds:

- formation of public credit history and improvement of credit rating 
- $\quad$ more funds compared to bank lending

- the possibility to raise funds for long periods

- interest rate is determined by the issuer;

- $\quad$ there is no pledge and warrant.

Disadvantages of issuing bonds:

- $\quad$ high costs of the issue procedure, such costs as state fees, payment of underwriter, lawyers service, presentations, advertising campaigns, etc.;

- a complicate procedure for processing documents and registering a bond issue with government authorities;

- the issuer is exposed to great risks, associated with a bonded debt issue activity.

- Of these, the most significant are the following;

- market risk, there is always the possibility of an adverse change in the market situation. There are such cases, that the placement of the issue occurs at a higher revenue to repayment in comparison with the predicted. Cases of incomplete placement of the issue are also known;

- temporary risk is associated with a delay in the registration of the Terms of the bond issue or a refusal to register them, and there is a need to quickly search for an alternative source of financing;

- tax risk;

- $\quad$ interest risk consists in changing refinancing rates by the Bank of Russia and changing the coupon rate (if the issue is with a variable coupon);

- legislative risk is the probability of a change in the revenue power of budgets of different levels. Its consequences are a budget deficit and an inability to repay one's own debt obligations;

- $\quad$ credit risk occurs in case of decline of the issuer's financial condition and, as a result, inability to be liable to its obligations;

- currency risk, refers to bonds, whose nominal value is denominated in foreign currency, consists in exchange rate changes in the currency market;

- liquidity risk, loss of liquidity in a particular issue.
From the end of January 2014, a wide range of non-resident foreign investors got access to the domestic sub-federal bond market due to the inclusion of these securities in the Euroclear international payments system. Obviously, it is possible to expect demand from non-resident investors for a limited number of sub-federal bonds of only the highestquality issuing regions. Nevertheless, the arrival of new investors may lead to a redistribution of portfolios and interests of domestic Russian investors.

Foreign investments. It should be noted, that foreign investments are also a source of financing of expanded reproduction of fixed assets. In accordance with the current legislation of the Russian Federation, foreign investors in the country are provided with full and unconditional legal protection. Art. 7 of the Federal Law "On foreign investments in the Russian Federation" contains a provision, that "foreign investments in the Russian Federation are not subject to nationalization and can not be subject to requisition or confiscation". However, it is further provided, that such measures are permitted "in exceptional cases, provided by law, when these measures are taken in the public interest". This legal duality gives the foregoing guarantees a indefinite status.

Either raised or borrowed funds can act as foreign investments. The most valuable and interesting are direct investments of foreign capital, since this, on the one hand, is more closely associated with the development of the real sector of the economy, with the use of advanced technologies and modern management and marketing methods, on the other hand, the state does not bear economic and political obligations on direct investments .

The main investors for Russia are Germany and Cyprus. In addition, fairly good business connections are established with Japan and China. Thus, it is possible to conclude, that the Russian economy is attracted towards the Asian segment of the global financial market. The geography of investment cooperation is very diverse. Companies from Germany are registered in $40 \%$ of the country's regions, from the USA - in $36.7 \%$, from Sweden - in 30\%, from China - in 20\%, from the UK - in $16.7 \%$, from France and Finland - in $13.3 \%$ A significant role in the economy of the Russian regions is played by Canada, Belgium, Holland, Austria, Italy, Norway, Switzerland, Denmark, Czech Republic, Turkey; Poland, Israel, South Korea, Cyprus, the Virgin Islands, Malaysia, Kazakhstan, and Ukraine have a less significant influence. International institutions - the World Bank for Reconstruction and Development (IBRD) and the European Bank for Reconstruction and Development (EBRD) - show moderate activity in Russian regions.

Like any other complicate economic phenomenon, foreign investments can have both positive and negative consequences on the national economy.

Advantages of foreign investments as a source of financing:

- an additional source of capital investments into the production of goods and services, in some cases carried out in the form of a transfer of technology, know-how, new management methods; 
- $\quad$ an increase in real investments, accelerating the rate of economic development and improving the country's balance of payments;

- use of local savings to implement effective projects;

- $\quad$ raising local capital and strengthening the local financial market through the use of its resources for production purposes;

- $\quad$ increasing employment, skills of the workforce;

- $\quad$ expanding the range of released products;

- reduction of currency costs for the payment of imports;

- $\quad$ expansion of exports and foreign exchange earnings;

- $\quad$ raising of living standards and consumer purchasing power ;

- development of infrastructure and services;

- increase in competition in the national economy and a decrease in its monopolization;

- increasing confidence in the country, which will attract new foreign investors.

The disadvantages or negative consequences of foreign investments include the following:

- repatriation of capital and transfer of profits in various forms (dividends, interest, etc.), which worsens the balance of payments of the host country;

- increase in dependence of the national economy, threatening its economic and political security;

- $\quad$ ignoring of local conditions and features by foreign investors;

- possible deformation of the structure of the national economy;

- increase in social tension, in particular, due to higher remuneration of labor at foreign enterprises;

- environmental degradation as a result of the transfer of "dirty" industries to the country and irrational use of local resources.

\section{CONCLUSION - CONCLUSIONS ON THIS STUDY AND PROSPECTS FOR FURTHER DEVELOPMENT OF THIS DIRECTION}

Institutional investors are considered to be reliable sources of financing of infrastructure due to their long-term investment horizon and the requirement for matching assets and liabilities. Asset-secured securitization of accounts receivable for public-private partnership (PPP) projects is considered as an alternative financial instrument to stimulate institutional investments. [14]

Large international financial institutions and funds can be as foreign investors [3]. In the world there are about 30 banks, specializing in project financing, and they participate in PPP transactions in different countries. There is a whole world system, specialized in the development of PPP programs.

A clear advantage of attracting an international financial organization in a PPP project is the possibility of obtaining a credit with a lower interest, the possibility to use the competence of an investor, the project becomes global, thereby reducing characteristic political risks [3].

For example, the Asian infrastructure investment bank has special infrastructure competencies, as do other specialized international financial organizations. Many international financial institutions such as the EBRD, IFC froze financing of PPP projects in Russia due to the imposed sanctions. But, as in the situation with import substitution, the main rate shifted to other markets; interest in Russian projects is demonstrated by Asian banks and development institutions, as well as funds from Arab countries.

Legal regulation of the activity of foreign investors in the Russian economy is carried out on the basis of the national regime.

In recent years, the Russian Direct Investment Fund (RDIF) has been a catalyst for foreign direct investments. At 2015, RDIF will make long-term connections not only with European funds, but also with Asian partners. In 2015, RDIF closed transactions with the State Bank of India and the Saudi Arabia Sovereign Fund (PIF), the Mubadala UAE fund, which plans to invest at least $\$ 5$ billion. The United States is involved in major infrastructure projects, namely the construction of the M-11 "Moscow - St. Petersburg" highway, the M-1 "Moscow - Minsk" highway, and the construction of the Central Ring Road in the Moscow Region. RDIF actively cooperates also with Russian companies to raise foreign investments [12].

There is another category of investors, these are subcontractors investors, including foreign ones. The main income of this category of investors is the profit from subcontracting. Such companies can also act as investors. This approach is most realized in Spain.

RDIF together with foreign investors plans to participate in financing the purchase of subway carriages for Moscow. The issue of financing transfer hubs is also being worked out [9].

As mentioned above, now the Russian Federation is actively establishing partnerships with Asian and Arab funds, in 
particular with the Asian Infrastructure Investment Bank (AIIB), which has already approved a $\$ 0.5$ billion sovereign loan for Russia to develop infrastructure [10]. Borrowed sources of financing are bank credits. Borrowed sources of financing of investments, that is, funds from other legal entities and individuals, temporarily raised in the form of loans, credits. They are provided to the organization for temporary use for a specified period on the terms of urgency, repayment and payment.

The return of borrowed funds is carried out at the expense of the organization's own and equivalent funds. Long-term financing of investment injections is risky, therefore, the lender reduces the risk for himself by legislatively established methods, for example, the requirement of pledge, guarantees of third parties or administrative bodies, control over the borrower's business activities, etc.

Russian experience shows, that lending of enterprises and the sphere of material production is not included in the circle of interests of commercial banking structures. They are even less inclined to search and select investment projects. High bank interest for a credit does not allow many enterprises to use this source of investment, so its share in the total investment is small. The "loans" group includes funds, borrowed from legal entities and individuals on a paid and repayable basis. An example of such a loan is the issue of bonds by an economic entity.

The main forms of borrowed financing of real investments are bank credits. Bank credits act as one of the most effective forms of external financing of real investments in cases, when companies cannot secure their implementation from own funds and issue of securities.

The attractiveness of this form is due primarily to the following factors:

- the possibility of developing a flexible financing scheme;

- $\quad$ using the effect of financial leverage, which allows to increase the return on equity, depending on the ratio of own to borrowed capital in the structure of invested funds and the cost of borrowed funds;

- the possibility to raise long-term financing for the implementation of investment projects with repayment according to a previously agreed schedule;

- $\quad$ relative speed of registration and low overhead costs for raising.

- But there are also disadvantages:

- the credit amount is limited by the current financial abilities of the company;

- $\quad$ pledge is required in excess of the credit amount;

- warranters are desirable.
- An important factor of the success of a company in raising a credit are the following components:

- $\quad$ high profit of the project, allowing to pay credit interest and pay off the principal debt;

- $\quad$ good credit history;

- $\quad$ availability of pledges and warranters.

Credit resources are, as a rule, medium- and long-term. The term for raising an investment credit is comparable with the terms for implementing an investment project. In this case, the credit may provide for the existence of a grace period, i.e., a period of deferral of repayment of the principal debt. Such a condition lightens the servicing of the credit, but increases its cost, since interest payments are calculated from the outstanding amount of debt. Credits in Russian practice are usually applied in the form of an urgent loan with a repayment period in the range of three to five years, based on the drawing up the corresponding credit agreement (agreement). In some cases, for this period the bank opens a credit line to the borrower. To finance real investments, standard mortgage loans can be used. The mortgage lending system provides a mechanism of accumulation and longterm lending at a low interest rate with installment payments for long periods. In the event of a long and close cooperation between the creditor bank and the borrower to finance real investments, the bank may open an investment credit line to the borrower. Its opening has several advantages for both the borrower and the lender. Advantages for the borrower are reduced overhead costs and time losses, associated with negotiating and concluding each separate credit agreement, as well as savings on interest-bearing servicing of credit amounts, that exceed the current financing needs of the investment project. For the creditor bank, in addition to reducing costs, associated with the execution and servicing of credit agreements, the tasks of refinancing (searching for sources) of credit funds are lightened and the risks of credit non-repayment are reduced, since the amount of individual tranches is less than the amount of the credit when it is onetime provided. At the same time, the creditor bank assumes the risks, associated with changes in the situation on the loan capital market, because regardless of the nature of these changes, it is obliged to fulfill its obligations to the borrower and provide credit to him in full accordance with the credit line agreement.

One of the varieties of credits, financing large infrastructure projects, is a syndicated credit.

Syndicated credits are provided to the largest enterprises with high earnings and a high share of imports. As a rule, syndicated credits are provided to enterprises with earnings of more than 6 billion rubles per year. With less earnings, enterprises use traditional credits. the minimum earnings among enterprises, that received a syndicated credit were in OJSC "Ruzkhimmash" - 7.6 billion rubles, and the maximum earnings were in the oil company "Rosneft" - 2.1 trillion rubles. Fourth, the bulk of transactions is in US dollars. One example of obtaining such a credit is: 
[13] Stochastic logistic fuzzy maps for the construction of integrated multirates scenarios in the financing of infrastructure projects/David Gonzalez-Ruiz, Juan; Pena, Alejandro; Alexander Duque, Eduardo; s soavtorami.

APPLIED SOFT COMPUTING Tom: 85 Nomer stat'i: 105818 Opublikovano: DEC 2019

[14] Assessment Framework for Financing PublicPrivate Partnership Infrastructure Projects through Asset-Backed Securitization/Lu, Zheng; Pena-Mora, Feniosky; Wang, S. Q.; s soavtorami. JOURNAL OF MANAGEMENT IN ENGINEERING Tom: 35 Vypusk: 6 Nomer stat'i: 04019027

[15] Islamic financing for Indonesia infrastructure project: mini hydropower plant case studies/ Rarasati, Ayomi Dita; Trigunarsyah, Bambang; Lamari, Fiona; s soavtorami.

INFRASTRUCTURE ASSET MANAGEMENT Tom: 6 Vypusk: 3 Str.: 195-205 Nomer stat'i: 1800004 Opublikovano: SEP 2019

[3] Plaksin V. K. Zarubezhnyy opyt finansirovaniya GCHP // Innovatsionnaya nauka. 2019. №5.

[4] Shevolkina K. L. Napravleniya razvitiya GCHP v infrastrukturnykh proyektakh / K. L. Shevolkina // Investitsii i innovatsii $\mathrm{v}$ real'nom sektore rossiyskoy ekonomiki: sostoyaniye i perspektivy: monografiya pod red. d.e.n., prof. Ye. B. Tyutyukinoy. - Moskva: Izdatel'sko-torgovaya korporatsiya «Dashkov i Ko», 2014. S.- 133-139.

[5] Budushcheye transportnoy infrastruktury [Elektronnyy resurs] - Rezhim dostupa: http://www.uncm.ru/Page304.html

[6] Yekaterinburg On-Layn Ye1 [Elektronnyy resurs] Rezhim dostupa: http://www.e1.ru/news/spool/news_id397652.html

[7] Internet gazeta Znak [Elektronnyy resurs] - Rezhim dostupa: https://www.znak.com/2016-1226/kuyvashev_2_uyu_ochered_metro_v_ekaterinburge _mogut_otdat_pod_upravlenie_chastnoy_kompanii

[8] Informatsionnyy portal Yekaterinburga [Elektronnyy resurs] - Rezhim dostupa: http://www.ekburg.ru/news/24/27399-aleksandr-yakobdal-start-proektirovaniyu-vtoroy-linii-metropolitena

[9] Informatsionnyy portal Yekaterinburga [Elektronnyy resurs] - $\quad$ Rezhim dostupa: https://www.ekburg.ru/news/24/27244-finansirovaniestroitelstva-metro-v-ekaterinburge-v-tsifrakh/

[10] Assotsiatsiya metro [Elektronnyy resurs]- Rezhim dostupa: http://asmetro.ru/

[11] Informatsionnyy portal 66.ru [Elektronnyy resurs] - Rezhim dostupa: https://66.ru/news/politic/225119/

[12] Zapadnyy skorostnoy diametr [Elektronnyy resurs]

- Rezhim dostupa: https://nch-spb.com/about/
[16] The geopolitics of South-South infrastructure development: Chinese-financed energy projects in the global South/Mohan, Giles; Tan-Mullins, May URBAN STUDIES Tom: 56 Vypusk: 7 Spetsial'nyy vypusk: SI Str.: 1368-1385 Opublikovano: MAY 2019

[17] EU-FINANCED PERIPHERAL LARGE-SCALE INFRASTRUCTURE PROJECTS AND THE WHITE ELEPHANT SYNDROME: THE EXAMPLE OF RAIL BALTICA/Veebel, Viljar; Markus, Raul; Ploom, Illimar.

ACTA OECONOMICA Tom: 69 Vypusk: 1 Str.: 1739 Opublikovano: MAR 2019

[18] Application of green banking on financing infrastructure project industry: environmental perspective/ Fashli, Arinal; Herdiansyah, Herdis; Handayani, Retty Dwi Konferentsiya: Joint Workshop on KO2PI / 1st International Conference on Advance and Scientific Innovation (ICASI) - Empowering Digital Society through Integration of Multidisciplinarity Aspect Mestopolozheniye: Medan, INDONESIA publ.: APR 23-24, 2018 1ST INTERNATIONAL CONFERENCE ON ADVANCE AND SCIENTIFIC INNOVATION Seriya knig: Journal of Physics Conference Series Tom: 1175 Nomer stat'i: 012027 Opublikovano: 2019 